\title{
High-spin $\rightarrow$ low-spin relaxation kinetics and metal dilution effects in 1D spin-crossover chain compounds
}

\author{
Chérif Baldé $^{\mathrm{a}, *}$, Mame Seyni Sylla ${ }^{\mathrm{a}}$, Cédric Desplanches ${ }^{\mathrm{b}}$, Guillaume Chastanet $^{\mathrm{b}}$ \\ a Laboratoire de Chimie et Physique des Matériaux (LCPM), Université Assane Seck de Ziguinchor, Senegal \\ ${ }^{\mathrm{b}}$ CNRS, Univ. Bordeaux, ICMCB UPR9048, 87 Avenue du Dr. Schweitzer, F-33600 Pessac, France
}

\section{Keywords:}

Spin Crossover (SCO)

Dilution effects

Light-induced spin switching

Metastable state lifetime

Molecular switches

\section{A B S T R A C T}

Light Induced Excited Spin State Trapping (LIESST) is a well known phenomenon in spin crossover (SCO) materials, studied since 1982 in solution and 1984 in the solid state, as it offers some interesting pro spects in data storage. In this paper we discuss the influence of metal dilution on the lifetime of the photo induced state in two 1D chain solid solution series: $\left[\mathrm{Fe}_{x} \mathrm{Zn}_{1} x_{x}(\mathrm{btzp})_{3}\right]\left(\mathrm{BF}_{4}\right)_{2}$ and $\left[\mathrm{Fe}_{x} \mathrm{Zn}_{1} x_{x}(\mathrm{endi})_{3}\right]$ $\left(\mathrm{BF}_{4}\right)_{2}$ \{btzp 1,2 bis(tetrazol $1 \mathrm{yl}$ )propane and endi 1,2 bis(tetrazol $1 \mathrm{yl}$ )ethane\}. For each composi tion, we have determined the thermal spin transition temperature, $T_{1 / 2}$, and the relaxation temperature of the photoinduced high spin state, $T$ (LIESST). A detailed analysis of the relaxation kinetics allowed a dis cussion of the evolution of this lifetime as a function of metal dilution.

\section{Introduction}

The recent developments in technology in which molecules or assemblies of molecules are used for information processing has enabled scientists to investigate their potential in several areas, namely for the development of display and memory devices [1]. Among them, the materials that undergo a spin crossover (SCO) phenomena upon application of external stimuli, such as tempera ture, pressure, light and electric field [2 6], have received a high interest within the construction of molecular devices with optical switch or/and magneto optical storage properties [7 17]. In this context, SCO coordination compounds of a $3 \mathrm{~d}^{4}$ to $3 \mathrm{~d}^{7}$ electronic configuration, displaying a central metallic ion in an octahedral environment, have been the focus of research for nearly 80 years [1 6]. Several aspects of the SCO phenomenon have been reviewed in the past $\left[\begin{array}{l}24,16 \\ 20\end{array}\right]$. Of these, by far the majority are pseudo octahedral $3 \mathrm{~d}^{6}$ iron(II) complexes, thus, as a function of the ligand field strength, the six electrons of the iron(II) ion can occupy the 3d orbitals in two different ways, giving rise to two different stable states: a diamagnetic low spin (LS) electronic configuration state $\mathrm{t}_{2 \mathrm{~g}}^{6} \mathrm{e}_{\mathrm{g}}^{0}\left({ }^{1} \mathrm{~A}_{1 \mathrm{~g}}, \mathrm{~S}=0\right)$ in the case of a strong ligand field and a paramag netic high spin (HS) electronic state $t_{2 g}^{4} e_{g}^{2}\left({ }^{5} T_{2 g}, S=2\right)$ when the ligand field is weak. In the case of an intermediate ligand field,

\footnotetext{
* Corresponding author.

E-mail address: cbalde@univ-zig.sn (C. Baldé).
}

the two spin states may become so close in energy that a small external perturbation can switch one state into the other.

LS $\leftrightarrow$ HS conversions are accompanied by profound changes in all the properties that depend on the distribution of the $3 \mathrm{~d}$ valence electrons. Besides the most obvious change of magnetic properties [21], including switchable diamagnetism $\leftrightarrow$ paramagnetism [10], the reversible change of color [10], refractive index [22], electrical conductivity, [23] luminescence, [24] non linear optical [25] and mechanical properties [26] may accompany the SCO. The bistabil ity of SCO materials can be addressed with the application of var ious external stimuli, like temperature [5,27], pressure [28 30], magnetic field [31,32] or light irradiation [5,27,33,34]. The optical switching is particularly regarded since ultrafast switches (fem toseconds) can be achieved [15]. Light can reversibly write and erase the LS and HS states according to the direct or reverse light induced excited spin state trapping (LIESST) effects [34 (d),35]. In 1998, Létard et al. introduced the T(LIESST) measurement, which aims to estimate the limiting temperature above which the photoinduced HS metastable state is erased $[19,36]$. From the determination of the $T$ (LIESST) value of several compounds, a comparison has been made in order to draw trends for chemists to increase the lifetime of the photo induced state [37]. In particular, the correlation between $T$ (LIESST) and $T_{1 / 2}$ was evidenced based on a $\left[T_{1 / 2} ; T\right.$ (LIESST)] database. From this $\left[T_{1 / 2} ; T\right.$ (LIESST)] database [36,37], Létard et al. observed a linear depen dence between $T$ (LIESST) and $T_{1 / 2}$ and extracted the empirical rela tionship $T($ LIESST $)=T_{0} \quad 0.3 T_{1 / 2}$ where $T_{0}$ is the initial value of the linear function. This phenomenological relationship appears to 
reflect rearrangement processes in the coordination sphere accom panying the SCO at the metal center. It is well documented that the crystal packing obviously plays a key role both on the thermal spin crossover feature, as often and early evidenced [19,20,38 41], and on the lifetime of the metastable state.

Dilution has proven to be an elegant way to learn more about cooperativity effects [ 42 46]. In fact, the first effect of dilution is to weaken the propagation of the elastic interactions between the $\mathrm{Fe}$ (II) SCO entities and, therefore, the cooperativity. Dilution also induces an internal pressure, positive or negative, depending on the ionic radius of the guest ion with respect to that of the HS $\mathrm{M}$ (II) ion. Dilution can be defined as the incorporation of isostruc tural M(II) complexes which do not exhibit SCO behavior towards the $\mathrm{Fe}$ (II) SCO crystal lattice. To date dilution has appeared very useful in understanding the thermal spin crossover and the relax ation behavior, but it is also a powerful tool to stabilize the photo induced metastable HS state $[22,47]$. This finding stimulates a true challenge towards applications in photonic devices, i.e. to identify the parameters affecting the lifetime of the photo induced excited state, with the ultimate goal to operate at room temperature [36].

In previous works we have studied extensively the effect of metal dilution on the LIESST temperature in mixed $\left[\mathrm{Fe}_{x} \mathrm{M}_{1}{ }_{x}\right]$ zero dimensional mononuclear complexes with various metal ions $[45,46]$. Whilst at a first glance the substitution of $\mathrm{Fe}(\mathrm{II})$ by $\mathrm{Zn}$ (II) ions appeared to not influence the T(LIESST), a comparison of sev eral other ions, such as $\mathrm{Mn}(\mathrm{II}), \mathrm{Cd}(\mathrm{II})$ and $\mathrm{Ni}(\mathrm{II})$, revealed a different picture. The use of anions bigger than the $\mathrm{Fe}(\mathrm{II})$ ion in its HS state induced an increase of the T(LIESST) of several degrees. On the con trary, insertion of $\mathrm{Ni}(\mathrm{II})$ ions, that is exactly inbetween $\mathrm{Fe}(\mathrm{II}) \mathrm{LS}$ and $\mathrm{Fe}$ (II) HS, induced a slight decrease of T(LIESST) [46g]. The effect of internal pressure, that has been widely documented on the thermal SCO, is also effective on the relaxation temperature $T$ (LIESST) and the lifetime of the photo induced state.

The goal of the present study is to investigate the influence of isomorphous metal dilution on the photo induced state's lifetime in SCO compounds of higher dimensionality than molecular com plexes, where the iron centers are linked together by covalent bonds, as a complement to our previous study on the relaxation temperature [46b]. We chose the two 1D compounds, $\left[\mathrm{Fe}_{x} \mathrm{Zn}_{1}{ }_{x}(\text { btzp })_{3}\right]\left(\mathrm{BF}_{4}\right)_{2}$ and $\left[\mathrm{Fe}_{x} \mathrm{Zn}_{1}{ }_{x}(\text { endi })_{3}\right]\left(\mathrm{BF}_{4}\right)_{2} \quad$ btzp $=1,2$ bis(tetrazol $1 \mathrm{yl}$ )propane and endi $=1,2 \mathrm{bis}$ (tetrazol $1 \mathrm{yl}$ )ethane , and diluted them gradually with zinc, which is appropriate for the formation of isomorphous mixed crystal series with iron(II) ions. The results are discussed on the basis of a kinetic study governing the photo induced back conversion. The two ligands endi and btzp are depicted in Scheme 1.

\section{Experimental}

\subsection{Chemicals}

General: All syntheses were carried out under a nitrogen atmo sphere. The syntheses of the ligands btzp [1,2 bis(tetrazol $1 \mathrm{yl}$ ) propane] and endi [1,2 bis(tetrazol $1 \mathrm{yl}$ )ethane] are described in the literature $[48,49]$.

Materials: The ligand 1,2 bis(tetrazol 1 yl)propane [btzp] was prepared from sodium azide, triethyl orthoformate and 1,2 diaminopropane according to the general method described by Kamiya and Saito [50]. The ligand 1,2 (tetrazol 1 yl)ethane [endi] was prepared in a similar method to that used by Satoh et al. [51]. The preparation of the pure compounds [Fe(btzp $\left.)_{2}\right]\left(\mathrm{BF}_{4}\right)_{2}$ and $\left[\mathrm{Fe}(\text { endi })_{2}\right]\left(\mathrm{BF}_{4}\right)_{2}$ has been described earlier by Gutlich et al. [48] and Linert et al. [49]. The diluted compounds $\left[\mathrm{Fe}_{x} \mathrm{Zn}_{1}{ }_{x}\right.$ ] were synthesised according to the same procedures, replacing iron(II) tetrafluoroborate by mixtures of iron(II) and zinc(II) in a given ratio. The iron fraction $(x)$ values were calculated from the iron and zinc atomic percentage determined by quantitative analysis. Elemental analyses of $\mathrm{C}, \mathrm{H}, \mathrm{N}$ and $\mathrm{F}$ were performed and the results agreed well with the calculated data (See Tables 1 and 2). The slight difference in values (about 1 for some doped compounds) may be due to minor errors made during the estimation of the iron and zinc atomic percentage, as determined by a microprobe spectrometer.

\section{2. $X$ ray powder diffraction}

Powder X ray diffraction measurements were conducted at room temperature in the range $2 \theta=1035^{\circ}$ for all compounds. Above $35^{\circ}$, the peak intensity was too weak to be relevant com pared to the background. The complete diffraction patterns of all the compounds are shown in Fig. 1. The presence of well defined peaks proves that these samples consisted of highly crystallized phases. Moreover, the positions of all of the (hkl) reflections match for all compounds of the $\left[\mathrm{Fe}_{x} \mathrm{Zn}_{1}{ }_{x}\right.$ (btzp)] and $\left[\mathrm{Fe}_{x} \mathrm{Zn}_{1}{ }_{x}\right.$ (endi)] ser ies. This observation shows that all these compounds are isostruc tural, without miscibility issues.

\subsection{Magnetic and photomagnetic studies}

Magnetic susceptibility data were collected using a Quantum Design MPMS 5 SQUID magnetometer under an applied field of $1 \mathrm{~T}$. All measurements were performed on homogenous polycrys talline samples and in the temperature range 10 to $290 \mathrm{~K}$. Diamag

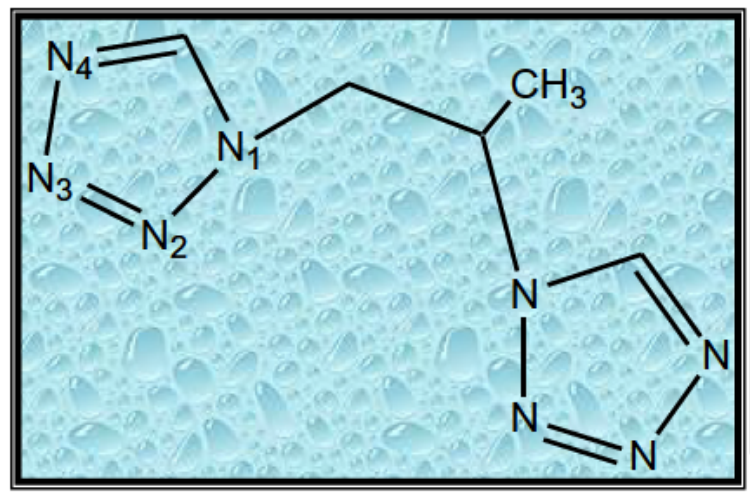

(I)

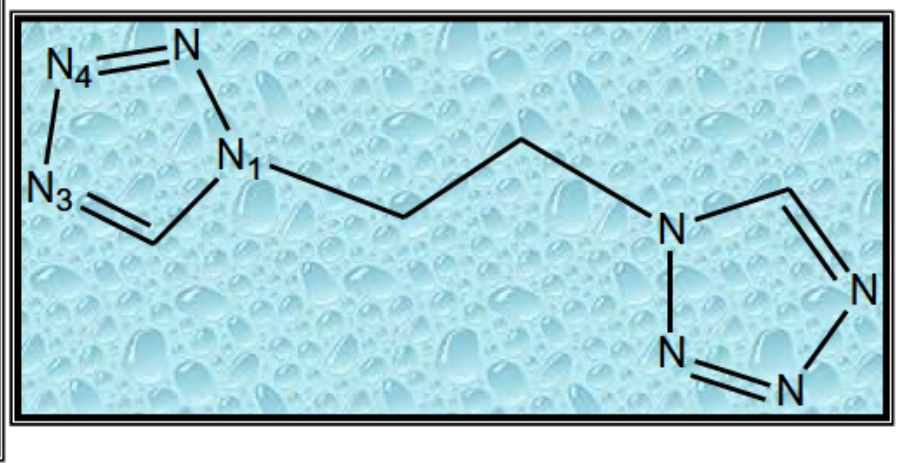

(II)

Scheme 1. Derivatives of the bis(tetrazol) ligand used in the present study. (I) 1,2-bis(tetrazol-1-yl)propane (btzp) and (II) 1,2-bis(tetrazol-1-yl)ethane (endi). 
Table 1

Elemental analysis for the mixed-crystal complexes: $\left.\left[\mathrm{Fe}_{x} \mathrm{Zn}_{1} \text { x(btzp }\right)_{3}\right]\left(\mathrm{BF}_{4}\right)_{2}$.

\begin{tabular}{|c|c|c|c|c|c|c|}
\hline \multirow[t]{2}{*}{ Compound } & \multicolumn{3}{|c|}{$\begin{array}{l}\text { Experimental } \\
\text { (\% weight) }\end{array}$} & \multicolumn{3}{|c|}{$\begin{array}{l}\text { Calculated } \\
\text { (\% weight) }\end{array}$} \\
\hline & C & $\mathrm{H}$ & $\mathrm{N}$ & C & $\mathrm{H}$ & $\mathrm{N}$ \\
\hline 1: $\left[\mathrm{Fe}(\mathrm{btzp})_{3}\right]\left(\mathrm{BF}_{4}\right)_{2}$ & 23.17 & 3.10 & 43.40 & 23.40 & 3.14 & 43.66 \\
\hline 2: $\left[\mathrm{Fe}_{0.72} \mathrm{Zn}_{0.28}(\mathrm{btzp})_{3}\right]\left(\mathrm{BF}_{4}\right)_{2}$ & 23.10 & 3.08 & 43.33 & 23.32 & 3.13 & 43.51 \\
\hline 3: $\left[\mathrm{Fe}_{0,4} \mathrm{Zn}_{0.6}(\mathrm{btzp})_{3}\right]\left(\mathrm{BF}_{4}\right)_{2}$ & 22.50 & 3.02 & 42.11 & 23.23 & 3.12 & 43.34 \\
\hline 4: $\left[\mathrm{Fe}_{0.17} \mathrm{Zn}_{0.83}(\text { btzp })_{3}\right]\left(\mathrm{BF}_{4}\right)_{2}$ & 22.21 & 3.01 & 42.08 & 23.16 & 3.11 & 43.22 \\
\hline 5: $\left[\mathrm{Fe}_{0.095} \mathrm{Zn}_{0.9}(\mathrm{btzp})_{3}\right]\left(\mathrm{BF}_{4}\right)_{2}$ & 22.20 & 3.00 & 42.01 & 23.14 & 3.11 & 43.18 \\
\hline
\end{tabular}

Table 2

Elemental analysis for the mixed-crystal complexes: $\left[\mathrm{Fe}_{x} \mathrm{Zn}_{1} \times(\text { endi })_{3}\right]\left(\mathrm{BF}_{4}\right)_{2}$.

\begin{tabular}{|c|c|c|c|c|c|c|}
\hline \multirow[t]{2}{*}{ Compound } & \multicolumn{3}{|c|}{$\begin{array}{l}\text { Experimental } \\
\text { (\% weight) }\end{array}$} & \multicolumn{3}{|c|}{$\begin{array}{l}\text { Calculated } \\
\text { (\% weight) }\end{array}$} \\
\hline & $\mathrm{C}$ & $\mathrm{H}$ & $\mathrm{N}$ & $\mathrm{C}$ & $\mathrm{H}$ & $\mathrm{N}$ \\
\hline 1: $\left[\mathrm{Fe}(\text { endi) })_{3}\right]\left(\mathrm{BF}_{4}\right)_{2}$ & 19.70 & 2.49 & 45.53 & 19.80 & 2.49 & 46.18 \\
\hline 2: $\left[\mathrm{Fe}_{0.85} \mathrm{Zn}_{0.15}(\text { endi })_{3}\right]\left(\mathrm{BF}_{4}\right)_{2}$ & 19.75 & 2.48 & 45.68 & 19.76 & 2.49 & 46.09 \\
\hline 3: $\left[\mathrm{Fe}_{0.49} \mathrm{Zn}_{0.51}(\text { endi })_{3}\right]\left(\mathrm{BF}_{4}\right)_{2}$ & 19.58 & 2.46 & 45.38 & 19.67 & 2.47 & 45.87 \\
\hline 4: $\left[\mathrm{Fe}_{0.29} \mathrm{Zn}_{0.71}(\text { endi })_{3}\right]\left(\mathrm{BF}_{4}\right)_{2}$ & 19.52 & 2.45 & 45.29 & 19.62 & 2.47 & 45.75 \\
\hline 5: $\left[\mathrm{Fe}_{0.093} \mathrm{Zn}_{0.9}(\text { endi })_{3}\right]\left(\mathrm{BF}_{4}\right)_{2}$ & 19.53 & 2.47 & 45.10 & 19.57 & 2.46 & 45.64 \\
\hline
\end{tabular}

$\left[\mathrm{Fe}_{\mathrm{x}} \mathrm{Zn}_{1-\mathrm{s}}(\mathrm{btzp})_{3}\right]\left(\mathrm{BF}_{4}\right)_{2}$

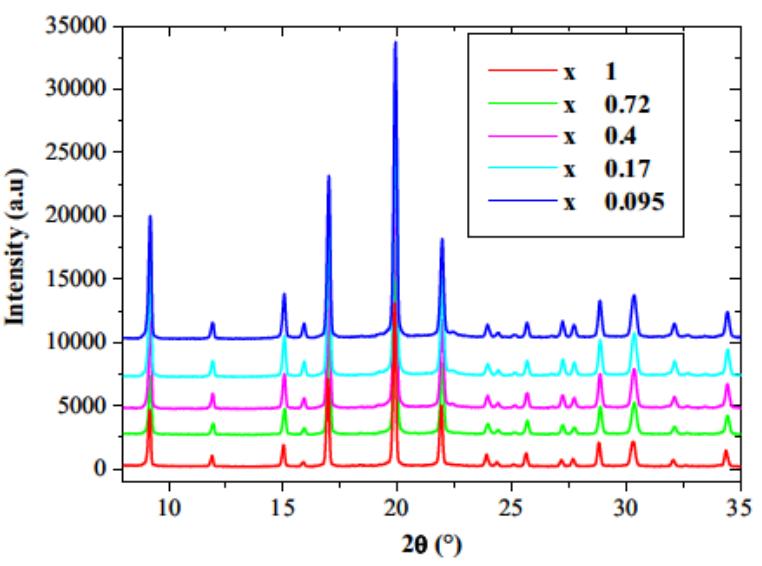

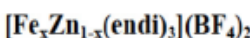

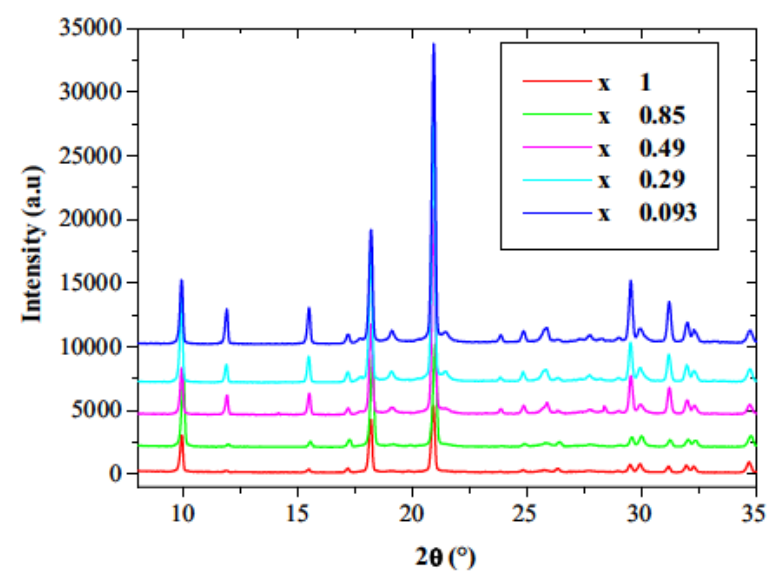

Fig. 1. Room temperature X-ray powder diffraction patterns of $\mathrm{Fe}_{x} Z \mathrm{n}_{1} \times$ (btzp)] (a) and $\left[\mathrm{Fe}_{x} \mathrm{Z} \mathrm{n}_{1}\right.$ (endi)] (b) series.

netic corrections for the sample holder and the material (using Pas cal constants) were applied.

Photomagnetic measurements were performed using a $\mathrm{Kr}^{+}$laser coupled via an optical fiber to the cavity of a MPMS 55 Quantum Design SQUID magnetometer operating at $2 \mathrm{~T}$. The crystalline sam ple was prepared in a thin layer $(\sim 0.1 \mathrm{mg})$ to promote full penetra tion of the irradiated light. The sample mass was obtained by comparison with the thermal spin transition curve measured on a larger accurately weighed polycrystalline sample. The calculated mass is of course approximate, however the adequacy between the bulk and thin layer magnetic measurements is reasonable, taking into account the fact that the data correction of such a low amount of sample is challenging. Our previously published standardized method for obtaining LIESST data was followed [36a]. The sample was first slowly cooled to $10 \mathrm{~K}$, ensuring that potential trapping of HS species at low temperatures did not occur. Irradiation was carried out at a set wavelength and the power of the sample surface was adjusted to $5 \mathrm{~mW} \mathrm{~cm}{ }^{2}$. Once photo saturation was reached, irradiation was ceased, the temperature increased at a rate of $0.3 \mathrm{~K} \mathrm{~min}^{1}$ to $\sim 100 \mathrm{~K}$ and the magnetization measured every $1 \mathrm{~K}$ to determine the T(LIESST) value [36,37], given by the extreme of the $\delta \chi_{M} T / \delta T$ versus $T$ curve for the relaxation. The $T$ (LIESST) value describes the limiting temperature above which the light induced magnetic high spin information is erased in a SQUID cavity. In the absence of irradiation, the magnetism was also measured over the temperature range $10290 \mathrm{~K}$ to follow the ther mal spin transition and to obtain a low temperature baseline. In addition to the T(LIESST) measurement, kinetic studies were per formed by irradiating the sample at $10 \mathrm{~K}$ until photo saturation, then, under constant irradiation, the sample was warmed to a desired temperature around the T(LIESST) region. At the desired temperature, irradiation was ceased and the decay of the magneti zation signal was followed for several hours, or until complete relaxation back to the low spin baseline.

\section{Results and discussion}

\subsection{Magnetic characterization}

The magnetic measurements were performed on polycrystalline samples and the thermal evolution of the molar magnetic suscep 
tibility, $\chi_{\mathrm{M}}$, time and the temperature were followed. The mea sured $\chi_{\mathrm{M}} T$ product is, in fact, the sum of the contributions of the iron(II) ions and zinc(II) ions (Eq. (1)). Based on these data and con sidering that the zinc(II) metal ion has a diamagnetic response in regard to the filled $3 \mathrm{~d}^{10}$ level, the iron(II) HS molar fraction, $\gamma_{\mathrm{HS}}$, may be directly deduced from the $\left(\chi_{\mathrm{M}} T\right)_{\mathrm{Fe}}$ product through Eq. (3), where $\left(\chi_{\mathrm{M}} T\right)_{\mathrm{Fe}}^{\mathrm{HT}}$ refers to the neat iron compound $(x=1)$ at high temperatures, typically at ambient temperature.

$$
\begin{aligned}
& \chi_{\mathrm{M}} T \quad x\left(\chi_{\mathrm{M}} T\right)_{\mathrm{Fe}}+\left(\begin{array}{ll}
1 & x
\end{array}\right)\left(\chi_{\mathrm{M}} T\right)_{\mathrm{Zn}} \\
& \left(\chi_{\mathrm{M}} T\right)_{\mathrm{Fe}} \frac{\chi_{\mathrm{M}} T \quad(1 \quad x)\left(\chi_{\mathrm{M}} T\right)_{\mathrm{Zn}}}{\chi} \\
& \gamma_{\mathrm{HS}} \frac{\left(\chi_{\mathrm{M}} T\right)_{\mathrm{Fe}}}{\left(\chi_{\mathrm{M}} T\right)_{\mathrm{Fe}}{ }^{\mathrm{HT}}}
\end{aligned}
$$

In a previous paper, we have investigated the mixed $\left[\mathrm{Fe}_{x} \mathrm{Zn}_{1}{ }_{x}\right.$ (btzp)] and $\left[\mathrm{Fe}_{x} \mathrm{Zn}_{1}\right.$ (endi)] compounds with the objec tive to study the influence of metal dilution on the T(LIESST) properties [46b]. Fig. 2 recalls the temperature dependence of the high spin fraction, $\gamma_{\mathrm{HS}}$, deduced from the magnetic susceptibility measurements for different metal dilution factors, $x$, for the two mixed crystal series $\left[\mathrm{Fe}_{x} \mathrm{Zn}_{1}{ }_{x}(\mathrm{btzp})_{3}\right]\left(\mathrm{BF}_{4}\right)_{2}$ and $\left.\left[\mathrm{Fe}_{x} \mathrm{Zn}_{1}{ }_{x} \text { (endi) }\right)_{3}\right]\left(\mathrm{BF}_{4}\right)_{2}$. As originally mentioned [46b], when $x$ decreases, (i) the spin crossover regime becomes more gradual, (ii) the thermal spin transition is lowered, and (iii) the residual HS fraction at low temperature increases. The information given by Fig. 2 is in fact close to the original studies of Gütlich et al. [42]. All that was so far explained in the following way:

(1) The increase of the gradual character with the metal dilution reflects the progressive loss of cooperativity, as expected from the increasing distance between active iron(II) metal centers in the diluted [Zn] lattice [5].

(2) The shift of the thermal spin transition towards lower tem perature can be understood through the change of internal pressure. The radius of the zinc(II) ion $(r=74 \mathrm{pm})$ is close to the ionic radius of the iron(II) HS ion ( $r=78 \mathrm{pm})$ and higher than the ionic radius of the iron(II) LS ion (61 pm) [52]. Thus, if iron(II) LS ions are highly diluted in a [Zn] lat tice, the zinc lattice induces a 'negative' pressure on the Fe (II) site, leading to an increase in the $\mathrm{Fe}-\mathrm{N}$ bond lengths (decrease of the crystal field potential) which favors the HS state $[5,53]$. On the contrary, the effect of zinc lattice is negligible when the iron(II) HS ions are highly diluted. Con sequently, the thermal spin transition, $T_{1 / 2}$, is shifted towards lower temperature with increasing metal dilution. This temperature is defined as the temperature at which the high spin fraction $\gamma_{\mathrm{HS}}$ is equal to the mean value of $\gamma_{\mathrm{HS}}$ at high and low temperature.

(3) The increase of the residual HS fraction at low temperature is also a consequence of the negative pressure occurring on the iron(II) LS ions in the highly diluted [Zn] lattice. The HS state is in fact stabilized by the [Zn] lattice.

\subsection{Photomagnetic properties}

The low $\rightarrow$ high spin photoconversion was investigated in bulk conditions using a SQUID magnetometer coupled to a continuous wave optical source. At $10 \mathrm{~K}$, the samples were irradiated with the most efficient wavelength to induce a LIESST effect, that is $532 \mathrm{~nm}$. In fact, it has been shown in our previous paper [46b] that the absorbance spectra recorded exhibit a broad band at $850 \mathrm{~nm}$ and a sharper band at $575 \mathrm{~nm}$. The band at $575 \mathrm{~nm}$ is attributed to both $\mathrm{d} \mathrm{d}$ and MLCT transitions of the LS spin complex, namely ${ }^{1} \mathrm{~A}_{1} \rightarrow{ }^{1} \mathrm{~T}_{1}$. On the other hand, the broad peak at $850 \mathrm{~nm}$ is attributed to a d d band of the HS state of the compound, namely the ${ }^{5} \mathrm{~T}_{2} \rightarrow{ }^{5} \mathrm{E}$ transition. Thus, $532 \mathrm{~nm}$ corresponds to a shoulder in the MLCT band of the diffuse absorption spectra. After light excitation at $532 \mathrm{~nm}$ at $10 \mathrm{~K}$, the temperature was increased in the dark to record the T(LIESST) curve. The $\chi_{\mathrm{M}} T$ product first increases upon warming from 10 to $30 \mathrm{~K}$ due to zero field splitting of the high spin iron(II) ion [37]. Then after a plateau, the $\chi_{\mathrm{M}} T$ value decreases sharply. The value of $\chi_{\mathrm{M}} \mathrm{T}$ at this plateau gives information about the efficiency of the photoswitching. T(LIESST) is determined by the minimum of the derivative $\partial\left(\chi_{M} T\right) / \partial T$ versus T (Inset, Figs. 3 and 4). Figs. 3 and 4 represent the temperature dependence of $\chi_{{ }_{M} T}$ for the differ ent mixed crystal systems $\left[\mathrm{Fe}_{x} \mathrm{Zn}_{1}{ }_{x}(\mathrm{btzp})_{3}\right]\left(\mathrm{BF}_{4}\right)_{2}$ and $\left[\mathrm{Fe}_{x} \mathrm{Zn}_{1}{ }_{x}(\right.$ endi $\left.)_{3}\right]\left(B_{4}\right)_{2}$, respectively, before and after irradiation. For all the complexes, a drastic increase of the magnetic signal under light irradiation was observed at $10 \mathrm{~K}$. It should, however, be noticed that the amount of iron in the photo excited high spin state is not the same for all the compounds, and for none of the complexes it is quantitative. The level of the percentage of photo conversion at $10 \mathrm{~K}$ has been calculated dividing the $\chi_{\mathrm{M}}$ T value after photo irra diation by the $\chi_{\mathrm{M}} \mathrm{T}$ value at room temperature. Depending on the compound and the metal dilution, this percentage varies from 61
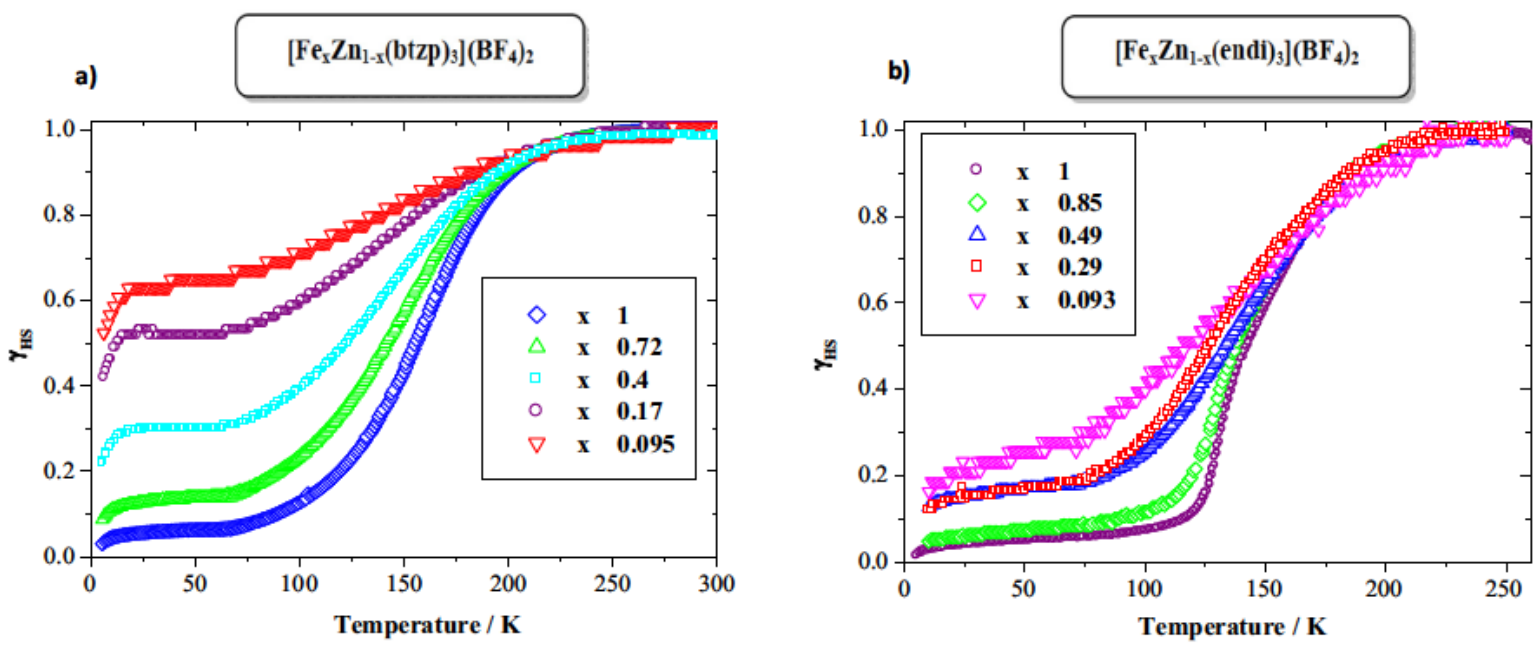

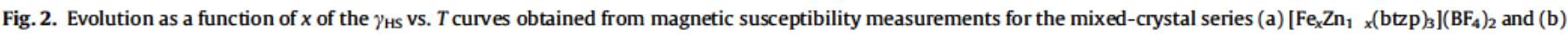
$\left[\mathrm{Fe}_{\mathrm{x}} \mathrm{Zn}_{1} \times\right.$ endi $\left._{3}\right]\left(\mathrm{BF}_{4}\right)_{2}$. 


\section{$\left[\mathrm{Fe}_{\mathrm{x}} \mathrm{Zn}_{1-\mathrm{s}}(\mathrm{btzp})_{3}\right]\left(\mathrm{BF}_{4}\right)_{2}$}
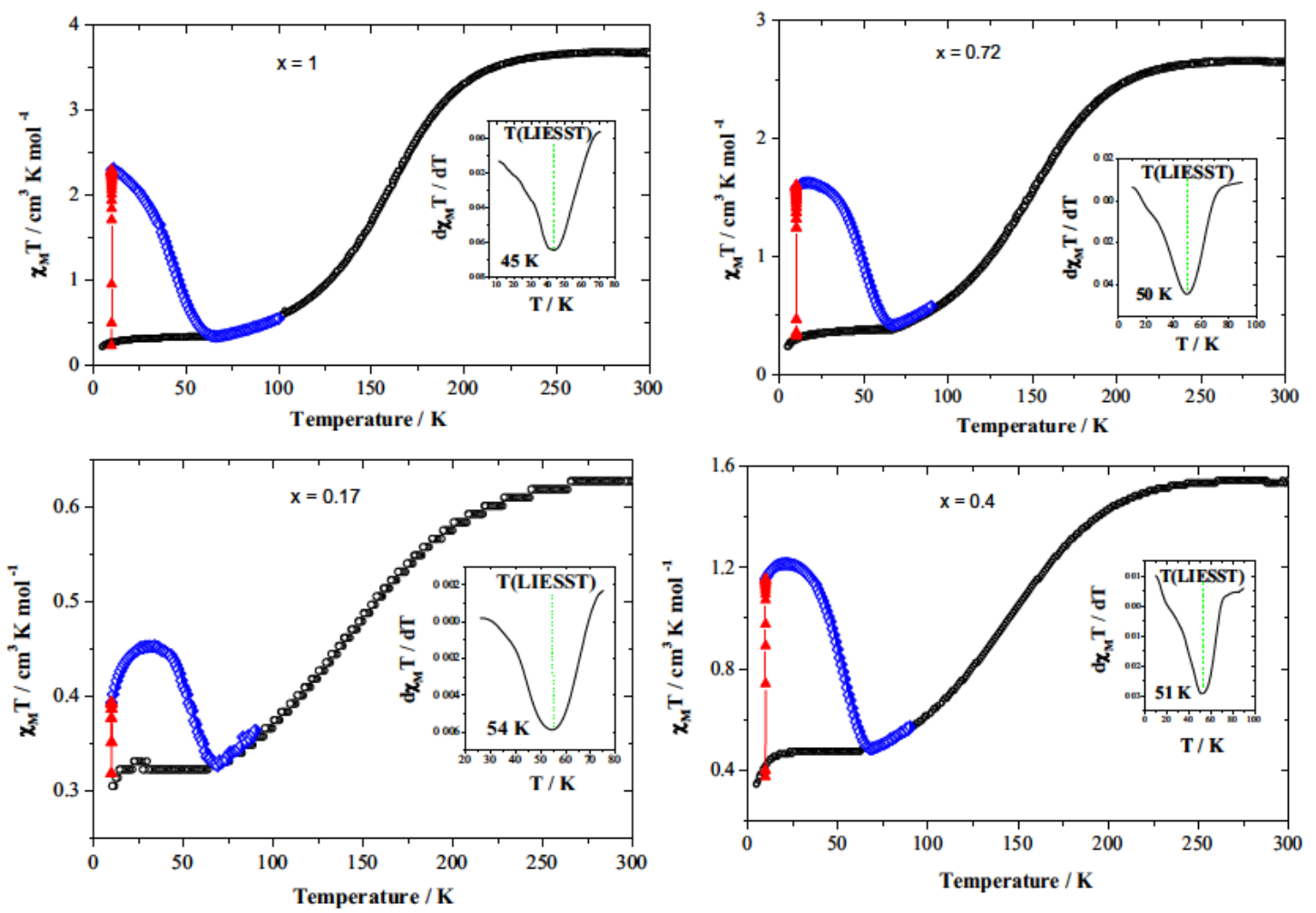

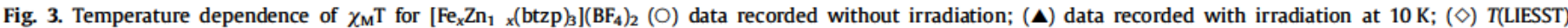
measurement, data recorded in the warming mode with the laser turned off after one hour of irradiation.

to $86 \%$. Values of $T$ (LIESST) are reported in Table 2. For the $\left[\mathrm{Fe}_{x}\right.$ $\left.\mathrm{Zn}_{1}{ }_{x}(\text { btzp })_{3}\right]\left(\mathrm{BF}_{4}\right)_{2}$ compounds, the change in T(LIESST) is some what more pronounced. It increases from $46 \mathrm{~K}(x=1)$ to $50 \mathrm{~K}$ $(x=0.72)$ and $51 \mathrm{~K}(x=0.4)$, reaching a value of $54 \mathrm{~K}(x=0.17)$. Attempts to determine a T(LIESST) value for $x=0.095$ were unsuccessful due to the weak $\chi_{M} \mathrm{~T}$ signal. For the samples of $\left[\mathrm{Fe}_{x} \mathrm{Zn}_{1}{ }_{x}(\text { endi })_{3}\right]\left(\mathrm{BF}_{4}\right)_{2}, T($ LIESST $)$ has been recorded between 61 and $63 \mathrm{~K}$ for $x$ values between 1 and 0.49 , and at $67 \mathrm{~K}$ for $x=0.29$. Determining a $T$ (LIESST) value for $x=0.093$ was unsuccessful due to the weak $\chi_{M} \mathrm{~T}$ signal.

\subsection{Relaxation kinetics}

To learn more about the influence of the kinetic parameters on the lifetime of the photo induced state in comparison to previous results, we systematically investigated the relaxation kinetics in the $40-70 \mathrm{~K}$ temperature range, where the HS $\rightarrow$ LS state relax ation is thermally activated for both systems and accessible with our SQUID apparatus. Figs. 5 and 6 display the relaxation processes for $\left[\mathrm{Fe}_{x} \mathrm{Zn}_{1}{ }_{x}(\mathrm{btzp})_{3}\right]\left(\mathrm{BF}_{4}\right)_{2}$ (with $x=1,0.72,0.4$ ) and $\left[\mathrm{Fe}_{x} \mathrm{Zn}_{1}{ }_{x}(\mathrm{endi})_{3}\right]\left(\mathrm{BF}_{4}\right)_{2} \quad$ (with $x=1,0.85,0.49$ ) respectively, recorded at different temperatures. Both materials show stretched exponential behavior such that incomplete relaxations are observed, even after 8 hours. Such stretched exponential shapes are typical for a broad distribution of relaxation times, which are expected to be associated with structural disorders, defects and inhomogeneities of photoexcitation. This behavior is also coherent for non cooperative systems. The relaxation curves for all the com pounds under investigation have been satisfactorily fitted (solid lines in Figs. 5 and 6) using the distribution of the activation energy involved in Eq. (4). The activation energy is supposed to have a normal (Gaussian) distribution with a standard deviation $\sigma\left(E_{a}\right)$.

$k_{H L}(T) \quad k_{0}+k_{\infty} \cdot \exp \left[E_{a} / k_{B} T\right]$

All the kinetic parameters, such as the apparent activation energy $E_{a}$, the apparent pre exponential factor, $k_{\infty}$, of the activated region, as well as the rate constant, $k_{0}$, of the quantum tunneling region, are calculated from the straight line fits given by the Arrhe nius plot $\ln k_{H L}(T)$ versus $1 / T$ (Figs. 5 and 6 ) and listed in Table 3. The rate constant $\mathrm{k}_{0}$ characterizes the relaxation in the quantum tunneling region and is estimated as an upper limit from the last complete kinetic recorded at the lowest temperature and was esti mated to be around $10^{4} s^{1}$. We observed that for the (btzp) ser ies, $E_{\mathrm{a}}$ increases with the dilution, whereas $k_{\infty}$ hardly changes. For the (endi) series, $E_{\mathrm{a}}$ and $k_{\infty}$ both increase with dilution.

\subsection{Discussion}

In the present study, we have fully investigated the kinetics of $\left[\mathrm{Fe}_{x} \mathrm{Zn}_{1}{ }_{x}(\mathrm{btzp})_{3}\right]\left(\mathrm{BF}_{4}\right)_{2}$ and $\left[\mathrm{Fe}_{x} \mathrm{Zn}_{1}{ }_{x}(\mathrm{endi})_{3}\right]\left(\mathrm{BF}_{4}\right)_{2}$ metal diluted materials to determine the evolution of the different kinetic parameters governing the metastable HS $\rightarrow$ LS relaxation process (activation energy, frequency factor). According to Eq. (4), an increase of $k_{\infty}$ will lead to a decrease of T(LIESST), whereas an increase of $E_{\mathrm{a}}$ will lead to an increase of $T$ (LIESST). For the [ $\mathrm{Fe}_{\mathrm{x}} \mathrm{Zn}_{1}$ $\left.{ }_{x}(\text { btzp })_{3}\right]\left(B_{4}\right)_{2}$ series, we observed that $E_{a}$ increases while $k_{\infty}$ remains almost constant on increasing the doping level, leading to an increase of the $T$ (LIESST) values. In the case of the $\left[\mathrm{Fe}_{x} \mathrm{Zn}_{1}\right.$ 


\section{$\left[\mathrm{Fe}_{\mathrm{x}} \mathrm{Zn}_{1-\mathrm{s}}\left(\mathrm{endi}_{3}\right]\left(\mathrm{BF}_{4}\right)_{2}\right.$}
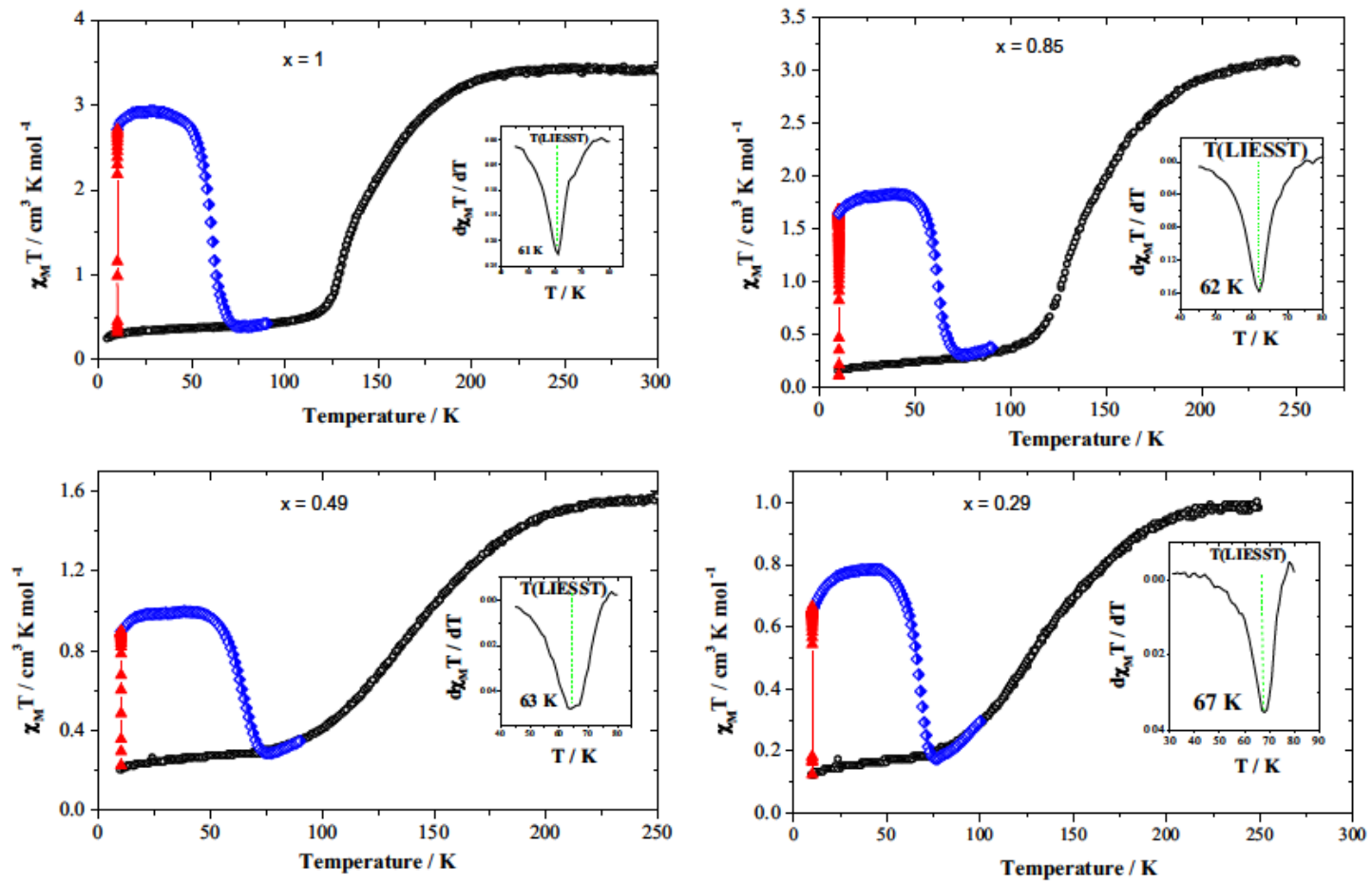

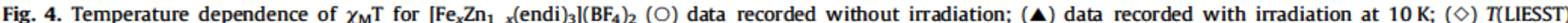

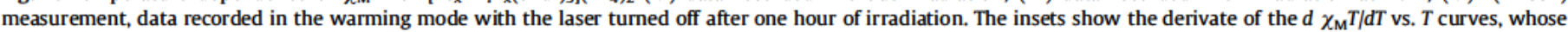
minimum corresponds to the T(LIESST) value.
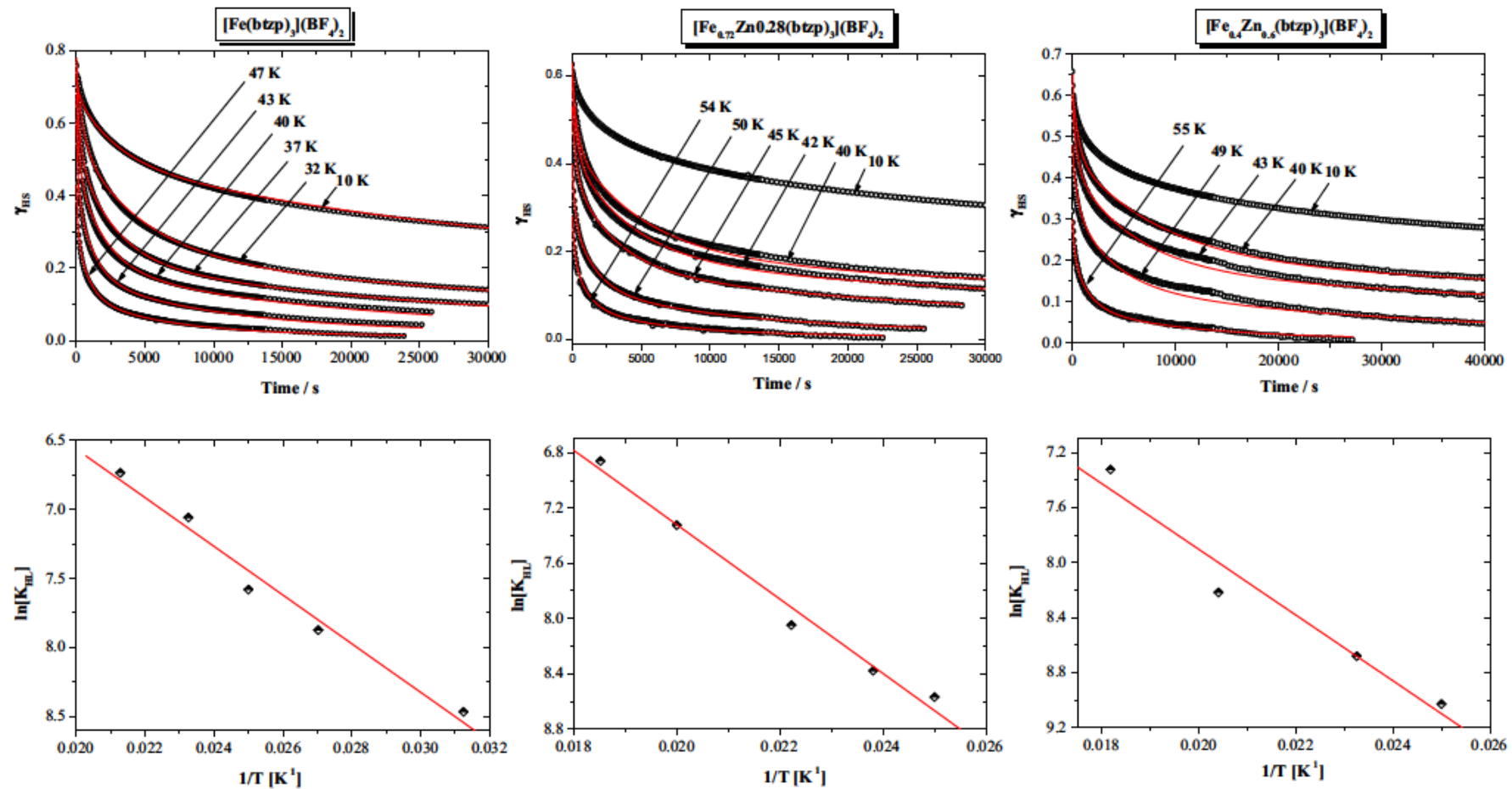

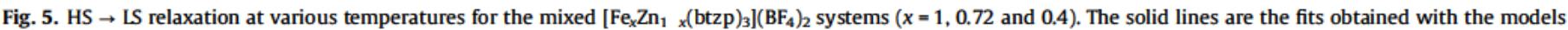
described in the text. The corresponding Arrhenius plot of $\ln \left(k_{\mathrm{HL}}\right)$ vs. 1/T are given in front. The solid lines represent the best linear simulations. 

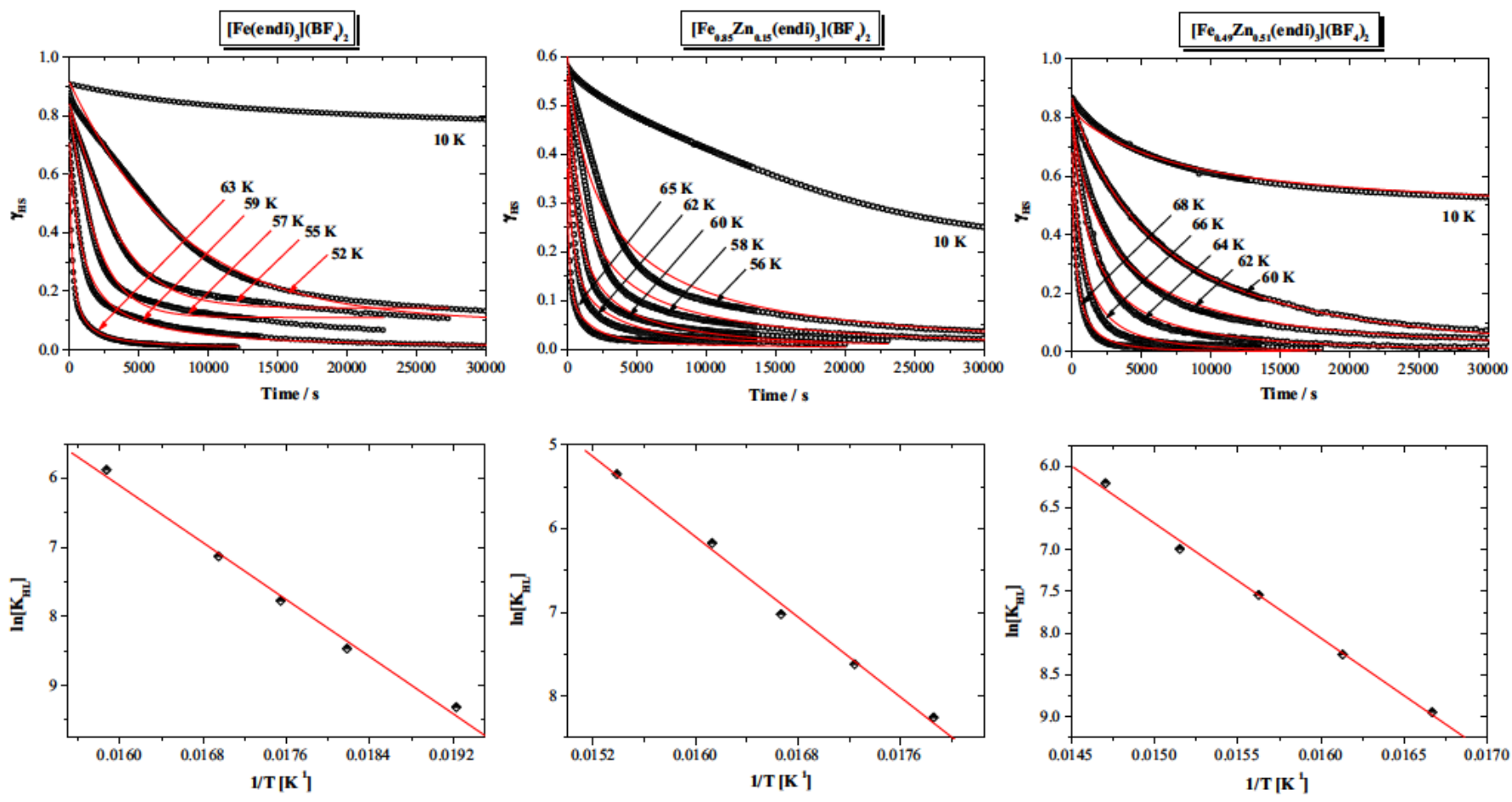

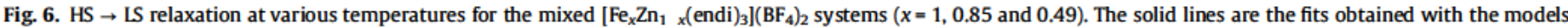
described in the text. The corresponding Arrhenius plot of $\ln \left(k_{\mathrm{HL}}\right)$ vs. 1/T are given in front. The solid lines represent the best linear simulations.

Table 3

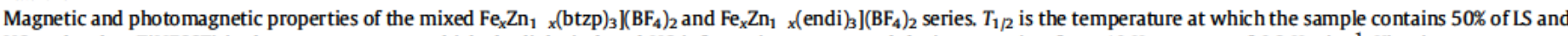

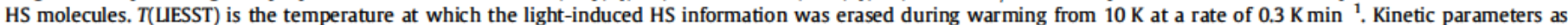
defined in Eqs. (5) and (6) are reported.

\begin{tabular}{|c|c|c|c|c|c|}
\hline SCO systems & $\begin{array}{l}T_{1 / 2} \\
(\mathrm{~K})\end{array}$ & $\begin{array}{l}\text { T(LIESST) } \\
(\mathrm{K})\end{array}$ & $\begin{array}{l}k_{\infty} \\
\left(s^{1}\right)\end{array}$ & $\begin{array}{l}E_{\mathrm{a}} \\
\left(\mathrm{cm}^{1}\right)\end{array}$ & $\begin{array}{l}\sigma\left(E_{\mathrm{a}}\right) \\
\left(\mathrm{cm}^{1}\right)\end{array}$ \\
\hline$\left[\mathrm{Fe}(\mathrm{btzp})_{3}\right]\left(\mathrm{BF}_{4}\right)_{2}$ & 158 & 46 & $5 \times 10^{2}$ & 122 & 10 \\
\hline$\left[\mathrm{Fe}_{0.72} \mathrm{Zn}_{0.28}(\mathrm{btzp})_{3}\right]\left(\mathrm{BF}_{4}\right)_{2}$ & 150 & 50 & $7 \times 10^{2}$ & 175 & 13 \\
\hline$\left[\mathrm{Fe}_{0,4} \mathrm{Zn}_{0,6}(\text { btzp })_{3}\right]\left(\mathrm{BF}_{4}\right)_{2}$ & 142 & 51 & $6 \times 10^{2}$ & 180 & 10 \\
\hline$\left[\mathrm{Fe}_{0.17} \mathrm{Zn}_{0.83}(\mathrm{btzp})_{3}\right]\left(\mathrm{BF}_{4}\right)_{2}$ & 135 & 54 & 1 & 1 & I \\
\hline$\left[\mathrm{Fe}(\text { endi })_{3}\right]\left(\mathrm{BF}_{4}\right)_{2}$ & 143 & 61 & $3.2 \times 10^{4}$ & 717 & 33 \\
\hline$\left[\mathrm{Fe}_{0.85} \mathrm{Zn}_{0.15}(\mathrm{endi})_{3}\right]\left(\mathrm{BF}_{4}\right)_{2}$ & 142 & 62 & $4.6 \times 10^{5}$ & 831 & 35 \\
\hline$\left[\mathrm{Fe}_{0,49} \mathrm{Zn}_{0.51}\left(\mathrm{endi}_{3}\right]\left(\mathrm{BF}_{4}\right)_{2}\right.$ & 138 & 63 & $1 \times 10^{6}$ & 956 & 33 \\
\hline$\left[\mathrm{Fe}_{0.29} \mathrm{Zn}_{0.71}(\mathrm{endi})_{3}\right]\left(\mathrm{BF}_{4}\right)_{2}$ & 136 & 67 & 1 & I & I \\
\hline
\end{tabular}

$\left.{ }_{x}(\text { endi })_{3}\right]\left(\mathrm{BF}_{4}\right)_{2}$ series, the situation is different. Both $E_{\mathrm{a}}$ and $k_{\infty}$ parameters increase with dilution. It seems that the metal dilution through the increase of $k_{\infty}$ and $E_{\mathrm{a}}$ parameters causes a kind of com pensation, leading to a smaller variation of T(LIESST) value as com pared to the $\left[\mathrm{Fe}_{x} \mathrm{Zn}_{1}{ }_{x}(\mathrm{btzp})_{3}\right]\left(\mathrm{BF}_{4}\right)_{2}$ series.

At this stage, it is interesting to compare the evolution of $T$ (LIESST) and $T_{1 / 2}$ as a function of dilution and discuss the observed behaviors on the basis of the relaxation kinetic parameters. Table 3 collects all the data obtained during this study and the results are reported in Fig. 7. The experimental data of $\left[\mathrm{Fe}_{x} \mathrm{Zn}_{1}{ }_{x}(\mathrm{btzp})_{3}\right]\left(\mathrm{BF}_{4}\right)_{2}$ and $\left[\mathrm{Fe}_{x} \mathrm{Zn}_{1} x(\text { endi })_{3}\right]\left(\mathrm{BF}_{4}\right)_{2}$ are close to the line $T_{0}=100$, in accord with the prediction of the Létard database for bidentate complexes. In other words, the values of $T$ (LIESST) and $T_{1 / 2}$ obey the relation $T$ $($ LIESST $)=T_{0} \quad 0.3 T_{1 / 2}$. According to this equation, in the $\left[\mathrm{Fe}_{x} \mathrm{Zn}_{1} \times(\right.$ btzp $\left.)_{3}\right]\left(\mathrm{BF}_{4}\right)_{2}$ series, the variation of $T_{1 / 2}$ from 158 to $135 \mathrm{~K}$, should lead to a variation of 7 degrees of T(LIESST). This agrees well with the current observation of an $8 \mathrm{~K}$ variation. In [ $\mathrm{Fe}_{x} \mathrm{Zn}_{1}{ }_{x}$ (endi) $\left.{ }_{3}\right]$ $\left(\mathrm{BF}_{4}\right)_{2}$, the $T_{1 / 2}$ value decreases from 143 to $136 \mathrm{~K}$, leading to an expected decrease of $T$ (LIESST) of only $2 \mathrm{~K}$. In this series, the agree ment between experiment and the linear relation $T($ LIESST $)=T_{0}$ $0.3 T_{1 / 2}$ is less good as T(LIESST) varies by $6 \mathrm{~K}$.

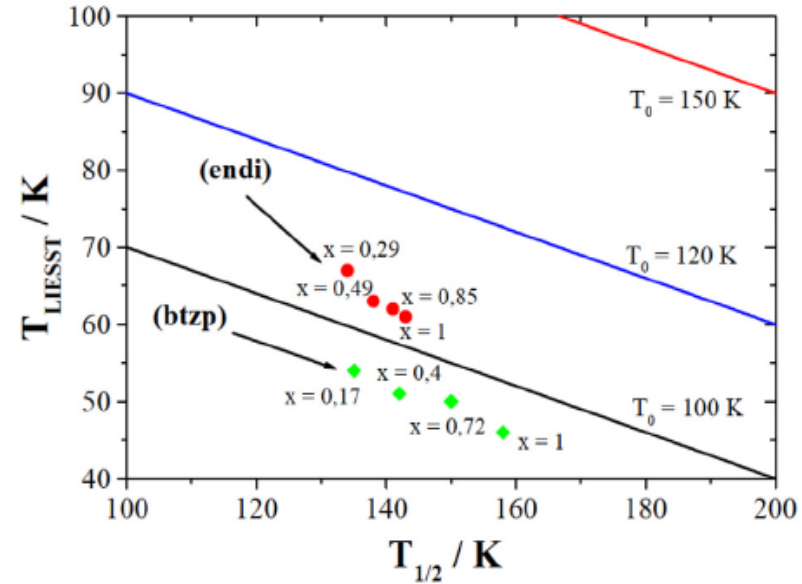

Fig. 7. HS $\rightarrow$ LS Evolution of the T(UESST) vs. $T_{1 / 2}$ for the mixed $\mathrm{Fe}_{x} \mathrm{Zn}_{1}{ }_{x}$ (btzp) $\left.{ }_{3}\right]$ $\left(\mathrm{BF}_{4}\right)_{2}$ and $\left.\mathrm{Fe}_{x} \mathrm{Zn}_{1}{ }_{x}(\text { endi })_{3}\right]\left(\mathrm{BF}_{4}\right)_{2}$ series. 
This result contrasts with that obtained for the zero dimen sional mononuclear compounds previously studied. Indeed, it was shown that $\mathrm{Zn}$ (II) dilution does not lead to any significant change of $T$ (LIESST) [46]. In the polymeric systems under study, the metal dilution does not follow this trend and moreover it does not exactly follow the $T$ (LIESST) versus $T_{1 / 2}$ empirical relationship. Even if the variations look minor, they are still not understood.

One clue to explain such behavior should lie in the relaxation rate, $k_{\infty}$. Indeed, despite the great structural similarity between the two series of compounds endi and btzp, $k_{\infty}$ has values that vary in magnitude. Hauser, on the basis of the SCC approach (Single Configurational Coordinate), predicted values of $k_{\infty}$ of the order of $10^{6} 10^{9} \mathrm{~s}^{1}[5,27,33,54]$. In SCC theory, the Fe ligand distance is taken as a reaction coordinate with a single vibration mode. Regarding the values of $k_{\infty}$, especially those relating to the endi and btzp series, it is reasonable to assume that a single reaction coordinate may not be sufficient to correctly describe the HS $\rightarrow$ LS transition. Therefore, the SCC approach may be insufficient, especially to obtain values of $k_{\infty}$ of the order of $10^{2} \mathrm{~s}{ }^{1}$. It becomes essential to consider a system that considers several modes of vibration to describe correctly the HS $\rightarrow$ LS relaxation. In 2006, Hauser has elsewhere proposed a model with two modes of vibration [53]. Compared to a single mode system, a system involving a low distortion mode vibration energy allows to the anticipation of low values of $k_{\infty}$. Interestingly, from a crystallo graphic point of view, the multimode theory, which takes into account the concept of distortion, is the most suitable for describ ing the spin crossover phenomenon. Indeed, a direct relationship has been established between the variation of the octahedron [ $\mathrm{FeN}_{6}$ ] distortion, $T_{1 / 2}$ and $T$ (LIESST) [20,55].

\section{Conclusions}

In the present work, we have investigated the effects of metal dilution on thermal properties and LIESST relaxation kinetics time/temperature dependence for $\left[\mathrm{Fe}_{x} \mathrm{Zn}_{1}{ }_{x}(\mathrm{btzp})_{3}\right]\left(\mathrm{BF}_{4}\right)_{2}$ and $\left[\mathrm{Fe}_{x}\right.$ $\left.\mathrm{Zn}_{1}{ }_{x}(\text { endi })_{3}\right]\left(\mathrm{BF}_{4}\right)_{2}$ SCO materials. As a first approximation, the results related to the compounds of the two series obey roughly a linear relationship between $T$ (LIESST) and $T_{1 / 2}$. Contrary to the dilution series of zero dimensional mononuclear compounds, the iron atoms in the compounds under study are not located in iso lated molecules, linked only by van der Waals forces or $\pi \pi$ stack ing, but are linked by covalent bonds. This can justify the somewhat different behaviors between the systems studied in this article and the previously studied dilution studies on zero dimen sional mononuclear compounds.

As far as kinetic parameters governing the metastable HS $\rightarrow$ LS relaxation process (activation energy, frequency factor) parameters are concerned, it appears that dilution increases the energy barrier, whereas the derived frequency factor is increased in the case of the $\left[\mathrm{Fe}_{x} \mathrm{Zn}_{1}{ }_{x}(\text { endi })_{3}\right]\left(\mathrm{BF}_{4}\right)_{2}$ series and remains essentially constant in the case of the $\left[\mathrm{Fe}_{x} \mathrm{Zn}_{1}{ }_{x}(\mathrm{btzp})_{3}\right]\left(\mathrm{BF}_{4}\right)_{2}$ series. It seems that, in both cases, the increased activation energy is not completely compen sated by the higher frequency factor, so that globally T(LIESST) is slightly increased with dilution.

\section{Acknowledgments}

The authors acknowledge the Department of Cooperation and Cultural Action Embassy of France to Dakar Sénégal, the University of Ziguinchor and its Department of Cooperation and Research, the Ministry of Higher Education and Research of Sénégal (Program FIRST) and Campus France. This work was also supported by the University of Bordeaux, France, the CNRS, the Region Nouvelle Aquitaine and by the LabEx AMADEus (ANR 10 LABX 42) within
IdEx Bordeaux (ANR 10 IDEX 03 02), i.e. the Investissements d'Avenir programme of the French government managed by the Agence Nationale de la Recherche. The ANR is also warmly acknowledged (ANR femtomat $n^{\circ} 13$ BS04 002). The authors also deeply thank the French network GdR MCM2 (Magnétisme et Com mutation Moléculaires) for the fruitful discussions the regular meetings provide. Finally, we warmly thank all the collaborators, visitors and experts for their confidence, interest and criticisms that helped a lot in the building of the database and the under standing of the phenomenon.

\section{Appendix A. Supplementary data}

Supplementary data to this article can be found online at https://doi.org/10.1016/j.poly.2018.11.046.

\section{References}

[1] (a) J.M. Lehn, Science 295 (2002) 2400;

(b) M. Ruben, U. Ziener, J.M. Lehn, V. Ksenofontov, P. Gütlich, G.B.M. Vaughan, Chem. Eur. J. 11 (2005) 94;

(c) M. Fujita, D. Oguro, M. Miyazawa, H. Oka, K. Yamaguchi, K. Ogura, Nature 378 (1995) 469;

(d) O.M. Yaghi, M. O’Keeffe, N.W. Ockwig, H.K. Chae, M. Eddaoudi, J. Kim, Nature 423 (2003) 705

[2] Spin-Crossover Materials, Properties and Applications, in: M.A. Halcrow (Ed.), John Wiley \& Sons, Ltd., 2013.

[3] (a) H.A. Goodwin, Top. Curr. Chem. 233 (2004) 59;

(b) G.J. Long, F. Grandjean, D.L. Reger, Top. Curr. Chem. 233 (2004) 91;

(c) H. Toftlund, J.-J. McGarvey, Top. Curr. Chem. 233 (2004) 151;

(d) P. Gütlich, Y. Garcia, H.A. Goodwin, Chem. Soc. Rev. 29 (2000) 419.

[4] Spin crossover in transition metal compounds, in: P. Gutlich, H.A. Goodwin (Eds.), Top. Curr. Chem., Springer, New York, 2004, pp. 233-235.

[5] P. Gütlich, A. Hauser, H. Spiering, Angew. Chem. 33 (1994) 2024.

[6] P. Gütlich, H.A. Goodwin, in: P. Gütlich, H.A. Goodwin (Eds.), Spin Crossover in Transition Metal Compounds I, no. 233 in Top. Curr. Chem., Springer, Berlin Heidelberg, 2004, pp. 1-47.

[7] O. Kahn, C.J. Martinez, Science 279 (1998) 44

[8] A. Bousseksou, G. Molnar, L. Salmon, W. Nicolazzi, Chem. Soc. Rev. 40 (2011) 3313.

[9] C. Lefter, R. Tan, S. Tricard, J. Dugay, G. Molnár, L. Salmon, J. Carrey, A. Rotaru, A. Bousseksou, Polyhedron 102 (2015) 434.

[10] P. Gütlich, H.A. Goodwin, Top. Curr. Chem. 233 (2004) 1.

[11] A.C. Aragonès, D. Aravena, J.I. Cerdà, Z. Acis-Castillo, H. Li, J.A. Real, F. Sanz, J. Hihath, E. Ruiz, I. Diez Perez, Nano Lett. 16 (2016) 218

[12] T. Miyamachi, M. Gruber, V. Davesne, M. Bowen, S. Boukari, L. Joly, F. Scheurer, G. Rogez, T. Kazu Yamada, P. Ohresser, E. Beaurepaire, W. Wulfhekel, Nat. Commun. 3 (2012), 938/1.

[13] G. Molnar, L. Salmon, W. Nicolazzi, F. Terki, A. Bousseksou, J. Mater. Chem. C 2 (2014) 1360.

[14] J.-F. Létard, P. Guionneau, L. Goux-Capes, Top. Curr. Chem. 235 (2004) 221.

[15] R. Bertoni, M. Cammarata, M. Lorenc, S. Matar, J.-F. Létard, H.-T. Lemke, E. Collet, Acc. Chem. Res. 48 (2015) 774.

[16] P. Gütlich, A.B. Gaspar, Y. Garcia, Beilstein J. Org. Chem. 9 (2013) 342.

[17] K.S. Kumar, M. Ruben, Coord. Chem. Rev. 346 (2017) 176.

[18] M.M. Khusniyarov, Chem. Eur. J. 22 (2016) 15178.

[19] G. Chastanet, C. Desplanches, C. Baldé, P. Rosa, M. Marchivie, P. Guionneau, Chem $^{2}$ (2018), https://doi.org/10.28954/2018.csq.07.001.

[20] P. Guionneau, Dalton Trans. 43 (2014) 382.

[21] (a) L.J. Kershaw Cook, R. Mohammed, G. Sherborne, T.D. Roberts, S. Alvarez, M. A. Halcrow, Coord. Chem. Rev. 289 (2015) 2 ;

(b) S. Brooker, Chem. Soc. Rev. 44 (2015) 2880

(c) R. Bertoni, M. Lorenc, A. Tissot, M.-L. Boillot, E. Collet, Coord. Chem. Rev. 282-283 (66-7) (2015) 6;

(d) A.B. Gaspar, M. Seredyuk, Coord. Chem. Rev. 268 (2014) 41;

(e) M.C. Munoz, J.A. Real, Coord. Chem. Rev. 255 (2011) 2068;

(f) I.A. Gass, S.R. Batten, C.M. Forsyth, B. Moubaraki, C.J. Schneider, K.S. Murray, Coord. Chem. Rev. 255 (2011) 2058;

(g) B. Weber, Coord. Chem. Rev. 253 (2009) 2432;

(h) H.-J. Krüger, Coord. Chem. Rev. 253 (2009) 2450;

(i) I. Krivokapic, M. Zerara, M.L. Daku, A. Vargas, C. Enachescu, C. Ambrus, P. Tregenna-Piggott, N. Amstutz, E. Krausz, A. Hauser, Coord. Chem. Rev. 251 (2007) 364;

(j) J.-F. Lètard, J. Mater. Chem. 16 (2006) 2550.

[22] A. Hauser, Coord. Chem. Rev. 111 (1991) 275.

[23] (a) A. Rotaru, I.A. Gural'skiy, G. Molnar, L. Salmon, P. Demont, A. Bousseksou, Chem. Commun. 48 (2012) 4163;

(b) E. Ruiz, Phys. Chem. Chem. Phys. 16 (2014) 14. 
[24] H.J. Shepherd, C.M. Quintero, G. Molnar, L. Salmon, A. Bousseksou, in: SpinCrossover Materials, Properties and Applications, John Wiley \& Sons, Ltd., 2013, pp. 347-373.

[25] P.G. Lacroix, I. Malfant, J.-A. Real, V. Rodriguez, Eur. J. Inorg. Chem. (2013) 615.

[26] M.D. Manrique-Juarez, S. Rat, L. Salmon, G. Molnar, C.M. Quintero, L. Nicu, H.J. Shepherd, A. Bousseksou, Coord. Chem. Rev. 308 (2016) 395.

[27] P. Gütlich, A. Hauser, H. Spiering, Angew. Chem. 106 (1994) 2971

[28] A.-H. Ewald, R.-L. Martin, E. Sinn, A.-H. White, Inorg. Chem. 8 (1969) 1837.

[29] P. Guionneau, E. Collet, Piezo- and photo-crystallography applied to spincrossover materials, John Wiley \& Sons Ltd, Oxford, UK, 2013, pp. 507-526, ch. 20.

[30] P. Gütlich, V. Ksenofontov, A.-B. Gaspar, Coord. Chem. Rev. 249 (2005) 1811.

[31] A. Bousseksou, N. Negre, M. Goiran, L. Salmon, J.-P. Tuchagues, M.-L. Boillot, K. Boukheddaden, F. Varret, Eur. Phys. J. B. 13 (2000) 451.

[32] S. Bonhommeau, G. Molnar, M. Goiran, K. Boukheddaden, A. Bousseksou, Phys. Rev. B: Condens. Matter 74 (2006) 064424.

[33] A. Hauser, Top. Curr. Chem. 234 (2004) 155.

[34] (a) M.-L. Boillot, J. Zarembowitch, A. Sour, Top. Curr. Chem. 234 (2004) 261; (b) B. Rosner, M. Milek, A. Witt, B. Gobaut, P. Torelli, R.-H. Fink, M.-M Khusniyarov, Angew. Chem., Int. Ed. 54 (2015) 12976;

(c) S. Venkataramani, U. Jana, M. Dommaschk, F.-D. Sonnichsen, F. Tuczek, R. Herges, Science 331 (2011) 445;

(d) S. Decurtins, P. Gütlich, C.-P. Kohler, H. Spiering, A. Hauser, Chem. Phys. Lett. 105 (1984) 1;

(e) E. Freysz, S. Montant, S. Létard, J.-F. Létard, Chem. Phys. Lett 394 (2004) 318 ;

(f) S. Bonhommeau, G. Molnar, A. Galet, A. Zwick, J.-A. Real, J.-J. McGarvey, A Bousseksou, Angew. Chem., Int. Ed. 44 (2005) 4069.

[35] A. Hauser, Chem. Phys. Lett. 124 (1986) 543.

[36] (a) J.-F. Létard, P. Guionneau, L. Rabardel, J.A.K. Howard, A.E. Goeta, D. Chasseau, O. Kahn, Inorg. Chem. 37 (1998) 4432;

(b) J.F. Létard, J. Mater. Chem. 16 (2006) 2550;

(c) J.F. Létard, P. Guionneau, O. Nguyen, J. Sanchez Costa, S. Marcén, G. Chastanet, M. Marchivie, L. Goux-Capes, Chem. Eur. J. 11 (2005) 4582.

[37] (a) J.-F. Létard, L. Capes, G. Chastanet, N. Moliner, S. Létard, J.A. Real, O. Kahn, Chem. Phys. Lett. 313 (1999) 115;

(b) S. Marcen, L. Lecren, L. Capes, H.A. Goodwin, J.-F. Létard, Chem. Phys. Lett. 358 (2002) 87;

(c) N. Shimamoto, S.-S. Ohkoshi, O. Sato, K. Hashimoto, Inorg. Chem. 41 (2002) 678.

[38] E. Collet, P. Guionneau, C.R. Chimie, 2018, in press. https://doi.org/10.1016/j. crci.2018.02.003.

[39] P. Guionneau, M. Marchivie, G. Bravic, J-F. Létard, D. Chasseau, in: P. Gütlich, H.-A. Goodwin (Eds.), Spin crossover in transition metal compounds II. Top. Curr. Chem., vol. 234, 2004, pp. 97.

[40] (a) M. Shatruk, H. Phan, B.-A. Chrisostomo, A. Suleimenova, Coord. Chem. Rev. 289 (2015) 62.

(b) H. Phan, J.-J. Hrudka, D. Igimbayeva, M. Lawson Daku, M. Shatruk, J. Am. Chem. Soc. 139 (2017) 6437;

(c) T.-A. Pfaffeneder, S. Thallmair, W. Bauer, B. Weber, New J. Chem. 35 (2011) 691.

[41] M.-A. Halcrow, Chem. Soc. Rev. 40 (2011) 4119.

[42] (a) M. Sorai, J. Ensling, P. Gütlich, Chem. Phys. 18 (1976) (1976) 199;

(b) P. Ganguli, P. Gütlich, E.W. Müller, Inorg. Chem. 21 (1982) 3429;

(c) J.-P. Martin, J. Zarembovitch, A. Bousseksou, A. Dworkin, J.G. Haasnoot, F. Varret, Inorg. Chem. 33 (1994) 6325.

[43] (a) T. Tayagaki, A. Galet, G. Molnar, M. Carmen Munoz, A. Zwick, K. Tanaka, J.A. Real, A. Bousseksou, J. Phys. Chem. B 109 (2005) 14859;

(b) C. Enachescu, U. Oetliker, A. Hauser, J. Phys. Chem. B 106 (2002) 9540; (c) R. Jakobi, H. Spiering, L. Wiehl, E. Gmelin, P. Gütlich, Inorg. Chem. 27 (1988) 1823;

(d) C. Enachescu, J. Linares, F. Varret, J. Phys.: Condens. Matter 13 (2001) 2481; (e) Z. Yu, T. Kuroda-Sowa, H. Kume, T. Okubo, M. Maekawa, M. Munakata, Bull. Chem. Soc. Jpn. 82 (2009) 333;

(f) J.-D. Cafun, L. Londinière, E. Rivière, A. Bleuzen, Inorg. Chim. Acta 361 (2008) 3555.

[44] (a) S. Zheng, M.-A. Siegler, J.-S. Costa, W.-T. Fu, S. Bonnet, Eur. J. Inorg. Chem. (2013) 1033;

(b) R. Ohtani, S. Egawa, M. Nakaya, H. Ohmagari, M. Nakamura, L.-F. Lindoy, S. Hayami, Inorg. Chem. 55 (2016) 3332;

(c) P. Chakraborty, C. Enachescu, C. Walder, R. Bronisz, A. Hauser, Inorg. Chem. 51 (2012) 9714;

(d) I. Krivokapic, P. Chakraborty, C. Enachescu, R. Bronisz, A. Hauser, Inorg. Chem. 50 (2011) 1856;

(e) P. Chakraborty, R. Bronisz, C. Besnard, L. Guenée, P. Pattison, A. Hauser, J. Am. Chem. Soc. 134 (2012) 4049.

[45] (a) N. Paradis, G. Chastanet, J.-F. Létard, Eur. J. Inorg. Chem. (2012) 3618; (b) N. Paradis, G. Chastanet, F. Varret, J.-F. Létard, Eur. J. Inorg. Chem. (2013) 968;

(c) N. Paradis, G. Chastanet, T. Palamarciuc, P. Rosa, F. Varret, K. Boukheddaden, J.-F. Létard, J. Phys. Chem. C. 119 (2015) 20039.

[46] (a) C. Baldé, C. Desplanches, A. Wattiaux, P. Guionneau, P. Gütlich, J.-F. Létard, Dalton Trans. (2008) 2702;

(b) C. Baldé, C. Desplanches, M. Grunert, Y. Wei, P. Gütlich, J.-F. Létard, Eur. J. Inorg. Chem. (2008) 5382;

(c) C. Baldé, C. Desplanches, P. Gütlich, E. Freysz, J.-F. Létard, Inorg. Chim. Acta 361 (2008) 3529;

(d) C. Baldé, C. Desplanches, F. Le Gac, P. Guionneau, J.-F. Létard, Dalton Trans. 43 (2014) 7820;

(e) C. Baldé, C. Desplanches, J-F. Létard, G. Chastanet, Polyhedron 123 (2017) 138 ;

(f) G. Lebedev, S. Pillet, C. Baldé, P. Guionneau, C. Desplanches, J.-F. Létard, IOP Conf. Se.: Mater. Sci. Eng. 5 (2009) 012025;

(g) M.-S. Sylla, C. Baldé, N. Daro, C. Desplanches, M. Marchivie, G. Chastanet, Eur. J. Inorg. Chem. (2017) 297;

(h) M.-S. Sylla, C. Baldé, N. Daro, G. Chastanet, J. Soc. Ouest-Afr. Chim. 043 (2017) 37.

[47] (a) J. Jeftic, A. Hauser, J. Phys. Chem. B 101 (1997) 10262;

(b) H. Romstedt, A. Hauser, H. Spiering, J. Phys. Chem. Solids 59 (1998) 265

(c) A. Vef, U. Manthe, P. Gutlich, A. Hauser, J. Chem. Phys. 101 (1994) 9326.

[48] P.J. van Koningsbruggen, Y. Garcia, O. Kahn, L. Fournès, H. Kooijman, A.L. Spek, J.G. Haasnoot, J. Moscovici, K. Provost, A. Michalowicz, F. Renz, P. Gütlich, Inorg. Chem. 39 (2000) 1891.

[49] J. Schweifer, P. Weinberger, K. Mereiter, M. Boca, C. Reichl, G. Wiesinger, G. Hilscher, P.J. Van Koningsbruggen, H. Kooijman, M. Grunert, W. Linert, Inorg. Chim. Acta 339 (2002) 297.

[50] T. Kamiya, Y. Saito, Ger. Offen. (1973) 2147023.

[51] Y. Satoh, N. Marcopulos, Tetrahedron Lett. 36 (1995) 1759.

[52] R.-D. Shannon, Acta Crystallogr., Sect. A 32 (1976) 751.

[53] A. Hauser, C. Enaschescu, M.L. Daku, A. Vargas, N. Amstutz, Coord. Chem. Rev. 250 (2006) 1642.

[54] (a) A. Hauser, A. Vef, P. Adler, J. Chem. Phys. 95 (1991) 8710;

(b) A. Hauser, J. Chem. Phys. 94 (1991) 2741;

(c) A. Hauser, Comments Inorg. Chem. 17 (1995) 17

(d) A. Hauser, J. Jeftic, H. Romstedt, R. Hinek, Mol. Cryst. Liq. Cryst. 286 (1996) 217.

[55] M. Marchivie, P. Guionneau, J.-F. Létard, D. Chasseau, Acta. Crystallogr., Sect. B 61 (2005) 25. 